\title{
Decrease in REM latency and changes in sleep quality parallel serotonergic damage and recovery after MDMA: a longitudinal study over 180 days
}

\author{
Eszter Kirilly $^{1,2}$, Eszter Molnar, ${ }^{1,2}$, Brigitta Balogh ${ }^{1,2}$, Sandor Kantor ${ }^{1,2}$, Stefan R. Hansson ${ }^{3}$, \\ Miklos Palkovits ${ }^{4}$ and Gyorgy Bagdy ${ }^{1,2,5}$ \\ ${ }^{1}$ Department of Pharmacology and Pharmacotherapy, Faculty of Medicine, Semmelweis University, Budapest, Hungary \\ ${ }^{2}$ Laboratory of Neurochemistry and Experimental Medicine, National Institute of Psychiatry and Neurology, Budapest, Hungary \\ ${ }^{3}$ Department of Obstetrics and Gynecology, Lund University Hospital, Lund, Sweden \\ ${ }^{4}$ Neuromorphological and Neuroendocrine Research Laboratory, Semmelweis University and Hungarian Academy of Sciences, \\ Budapest, Hungary \\ ${ }^{5}$ Group of Neuropsychopharmacology, Semmelweis University and Hungarian Academy of Sciences, Budapest, Hungary
}

\begin{abstract}
The recreational drug ecstasy [3,4-methylenedioxymethamphetamine (MDMA)], has been found to selectively damage brain serotonin neurons in experimental animals, and probably in human MDMA users, but detailed morphometric analyses and parallel functional measures during damage and recovery are missing. Since there is evidence that serotonin regulates sleep, we have compared serotonergic markers parallel with detailed analysis of sleep patterns at three time-points within $180 \mathrm{~d}$ after a single dose of $15 \mathrm{mg} / \mathrm{kg}$ MDMA in male Dark Agouti rats. At $7 \mathrm{~d}$ and $21 \mathrm{~d}$ after MDMA treatment, significant $(30-40 \%)$, widespread reductions in serotonin transporter (5-HTT) density were detected in the cerebral cortex, hippocampus, most parts of the hypothalamus, and some of the brainstem nuclei. With the exception of the hippocampus, general recovery was observed in the brain $180 \mathrm{~d}$ after treatment. Transient increases followed by decreases were detected in 5-HTT mRNA expression of dorsal and median raphe nuclei at $7 \mathrm{~d}$ and $21 \mathrm{~d}$ after the treatment. Significant reductions in rapid eye movement (REM) sleep latency, increases in delta power spectra in non-rapid eye movement sleep and increased fragmentation of sleep were also detected, but all these alterations disappeared by the 180th day. The present data provide evidence for long-term, albeit, except for the hippocampus, transient changes in the terminal and cellular regions of the serotonergic system after this drug. Reduced REM latency and increased sleep fragmentation are the most characteristic alterations of sleep consistently described in depression using EEG sleep polygraphy.
\end{abstract}

Received 24 April 2007; Reviewed 27 July 2007; Revised 12 December 2007; Accepted 19 December 2007; First published online 8 February 2008

Key words: Depression, dorsal raphe nucleus, median raphe nucleus, MDMA, REM latency, serotonin transporter.

\section{Introduction}

'Ecstasy' [3,4-methylenedioxymethamphetamine (MDMA)], an amphetamine analogue used recreationally by humans, has been found to damage

Address for correspondence: G. Bagdy, Ph.D., Department of Pharmacology and Pharmacotherapy, Faculty of Medicine, Semmelweis University, Budapest, Nagyvarad ter 4, H-1089, Hungary.

Tel. : +3614591495 Fax: +3614591494

E-mail:bag13638@mail.iif.hu brain serotonin (5-HT) neurons in experimental animals, and reportedly, possibly also in human MDMA users (McCann et al., 1998, 2005; Semple et al., 1999).

The acute effects of MDMA involve several neurotransmitters, e.g. monoamines and acetylcholine, but the long-term effects are selective for the serotonergic system in the brain (Colado et al., 1999; Green et al., 2003) and thus the serotonergic system might serve as a model for selective, partial lesion of this system. In animal models, marked reductions were observed in 
the concentration of 5-HT, 5-hydroxyindolacetic acid and serotonin transporter (5-HTT) density (Battaglia et al., 1987; Colado et al., 1993; Green et al., 2003; Sabol et al., 1996). There is also evidence that MDMA causes a selective loss of 5-HT axons of a particular morphological subtype, the so-called 'fine' 5-HT fibres, whilst sparing 'beaded' 5-HT fibres. Based mainly on these findings, it has been proposed that MDMA is more toxic to 5-HT projection neurons in the dorsal raphe nucleus (DRN) than those in the median raphe nucleus (MRN) (Molliver et al., 1989; O'Hearn et al., 1988). However, expression of 5-HTT mRNA in the raphe nuclei has not been examined; consequently, direct comparisons of responses of dorsal and other raphe nuclei have not been measured.

5-HT plays a key role in the regulation of sleep, especially rapid eye movement (REM) sleep (Portas et al., 1996). Initiation and duration of REM sleep is modulated by the serotonergic system (Adrien, 2002; Portas et al., 1996). Increase in extracellular 5-HT concentration by 5-HT releasers, 5-HT reuptake blockers or several 5-HT receptor agonists may increase REM latency (Monti and Monti, 1999; Sommerfelt and Ursin, 1991; Ursin, 2002). Preclinical studies involving pharmacological depletion or anatomical lesions of 5-HT neurons have generally shown changes in REM and non-rapid eye movement (NREM) sleep. However, most of these preclinical studies involved massive depletions of 5-HT with sleep studies generally performed shortly after lesioning (Allen et al., 1993; Koella et al., 1968; Touret et al., 1991).

The present study was designed to characterize MDMA-induced damage and recovery of the serotonergic system including both cellular and terminal events. Furthermore, we hypothesized that longlasting partial damage and recovery of this system will be manifested in changes of sleep parameters. For these purposes we investigated parallel changes in 5-HTT mRNA expression in two raphe nuclei, 5-HTT fibre densities in several brain areas, and 16 functional measures of sleep in response to MDMA administration at three time-points within $180 \mathrm{~d}$.

\section{Method}

\section{Animals}

All animal experiments were carried out in accordance with the European Communities Council Directive of 24 November 1986 (86/609/EEC) and the National Institutes of Health Principles of Laboratory Animal Care (NIH Publications No. 85-23, revised 1985), as well as specific national laws (the Hungarian
Governmental Regulation about Animal Studies, 31 December 1998). Permission was also obtained from the local ethical committees. Male Dark Agouti rats aged $7 \mathrm{wk}$ (Harlan, Olac Ltd, Shaw's Farm, Blackthorn, Bicester, Oxon, UK) were used in the experiments. The animals (four per cage) were kept under controlled environmental conditions (temperature $21 \pm 1{ }^{\circ} \mathrm{C}$, and a $12 \mathrm{~h}$ light-dark cycle, lights on at 06:00 hours). Standard food and drinking water were freely available.

\section{Drug administration and treatment protocol}

( \pm )3,4-Methylenedioxymethamphetamine hydrochloride (MDMA, certified reference compound, purity $>99.5 \%$ ) was kindly provided by Professor Istvan Hermecz (Sanofi-Synthelabo-Chinoin, Budapest, Hungary). The drug was dissolved in $0.9 \% \mathrm{NaCl}$ at a dose equivalent to $15 \mathrm{mg} / \mathrm{kg}$ free base and was injected intraperitoneally in a volume of $1 \mathrm{ml} / \mathrm{kg}$. Control animals received an injection of $0.9 \% \mathrm{NaCl}$ in a volume of $1 \mathrm{ml} / \mathrm{kg}$. To measure the time-course of 5-HTT mRNA expression after MDMA treatment, in-situ hybridization histochemistry was performed $3,7,21$ and $180 \mathrm{~d}$ after drug treatment $(n=48$, six animals in each control and treated group at the four time-points). In parallel, the density of serotonergic fibres was assessed in separate group of rats using 5-HTT immunohistochemistry ( $n=5-6$ per group). Separate groups of animals were used for vigilance studies ( $n=6-9$ per group).

\section{In-situ hybridization histochemistry}

In-situ hybridization was performed as previously described (Hansson et al., 1998; Kovacs et al., 2007). After hybridization, sections were exposed to a BAS-MS 2340 Imaging Plate (FujiPhotoFilm Co. Ltd, Tokyo, Japan) for 6-13 d, depending on the intensity of the hybridization signal. The hybridization signals were quantified with ImageJ 1.32j imaging software (Wayne Rasband, NIH, Bethesda, MD, USA). For quantification, we averaged 9-9 sections for the DRN (between -9.30 and $-7.30 \mathrm{~mm}$ from the level of bregma) and 8-8 for the MRN (between -8.30 and $-7.30 \mathrm{~mm}$ from the level of bregma) per animal. The exact topography of these regions was determined according to a conventional rat brain atlas (Paxinos and Watson, 2005). The mean grey values over the DRN or MRN were measured on the film autoradiograph, and also over a similar size of the surrounding area that did not contain serotonergic cells. Differences measured in grey density were used for evaluation and statistical analysis. 
To obtain more precise measures for the effects of MDMA, 5-HTT mRNA expression of individual cells was counted. The sections were coated with nuclear track emulsion (NTB-2, Kodak, Rochester, NY, USA) for $4 \mathrm{wk}$ at $4{ }^{\circ} \mathrm{C}$. For each experimental animal, 4-4 sections were analysed, and the number of silver grains was measured over serotonergic cell bodies ( 25 or 10 cells in the DRN and MRN, in each section, respectively). The threshold was adjusted to the background signal level, the area in question was selected and the mean grey density was automatically calculated with respect to the surface area of the selected section. The mean grey density values reflect the mRNA expression of the cell.

\section{Immunohistochemistry}

The animals were deeply anaesthetized with nembutal, and perfused transcardially with Zamboni fixative solution. Brains were removed and post-fixed overnight at $4{ }^{\circ} \mathrm{C}$ in fixing solution. Free-floating $40-\mu \mathrm{m}$-thick coronal sections were cut using a freezing microtome. The presence of 5-HTT was detected using a 1:3000 dilution of a rabbit polyclonal anti-5-HTT antibody (Oncogene, San Diego, CA, USA). Immunostaining was developed with a peroxidase/DAB kit (EnVision $^{\mathrm{TM}}$, Dako, Glostrup, Denmark).

Monochrome digital images were made using similar light microscopic settings (Olympus BX51, objective, aperture, exposure time) at $\times 40$ magnification. Four to six representative, non-overlapping photographs were taken in each anatomical region: hippocampus (dentate gyrus, CA1, CA2, CA3) (3.60-3.20 mm caudal to bregma), hypothalamus (posteroventral preoptic areas $(0.30-0.40 \mathrm{~mm})$, lateral hypothalamic area $(3.60-3.20 \mathrm{~mm})$, posterior hypothalamic nucleus $(3.60-4.30 \mathrm{~mm})$, paraventricular nucleus $(1.50-2.10 \mathrm{~mm})$, suprachiasmatic nucleus (SCN) (0.90-1.40 mm), tuberomamillary nucleus (3.80-4.00 mm), cerebral cortex layers I-II [somatosensory and somatomotor cortex (3.30-2.30 mm)], periaqueductal grey [ventrolateral and dorsomedial part $(7.80-8.30 \mathrm{~mm})]$, peripeduncular tegmental nucleus $(7.80-8.30 \mathrm{~mm})$ and medial pontine reticular formation (8.80-7.80 mm).

Quantitative analysis of serotonergic fibre density was performed using analySIS image software (Soft Imaging System $\mathrm{GmbH}$, Lakewood, CO, USA). The positively stained fibres were distinguished from the background by means of density thresholding, and the area occupied by immunostained fibres was determined and recorded as a percentage of the total image area.

\section{Vigilance studies}

Surgery

Animals were chronically equipped with electroencephalogram (EEG) and electromyogram (EMG) electrodes, as described previously (Filakovszky et al., 2001; Kantor et al., 2002). Surgery was performed under halothane (2\%) anaesthesia (Fluotec 3) using Kopf stereotaxic instrument. After a $10-\mathrm{d}$ recovery period, the rats were attached to the polygraph by a flexible recording cable and an electric swivel, fixed above the cages, permitting free movement of the animals. To habituate the animals to the recording conditions, the rats were attached to the polygraph and received intraperitioneal injections of physiological saline daily for $5 \mathrm{~d}$ before the experiments.

\section{Sleep recording and scoring}

EEG, EMG and motor activity were recorded for $24 \mathrm{~h}$ periods, starting at light onset as described earlier (Gottesmann, 1992; Kantor et al., 2002). The vigilance states were scored visually for 4 -s periods for the first $2 \mathrm{~h}$ after light onset using conventional criteria (Kantor et al., 2002, 2004). The polygraphic recordings were classified by sleep analysis software for the 24-h recordings (SleepSign for Animal, Kissei Comtec America Inc.). EEG power spectra were computed for consecutive 4-s epochs at the frequency range of $0.25-30 \mathrm{~Hz}$ (fast Fourier transformation routine, Hanning window; frequency resolution, $0.25 \mathrm{~Hz}$ ) (Kantor et al., 2002, 2005).

The sleep variables were divided into four groups: REM and NREM [light slow-wave sleep (SWS-1) plus deep slow-wave sleep (SWS-2)] sleep indexes, wake parameters before and at around activity (dark) onset and sleep continuity. The REM sleep parameters included REM latency [the time elapsed from sleep onset until the first seven consecutive epochs of REM sleep (Mendelson, 1996), duration of REM in the first hour (calculated from the beginning of light onset), time of REM maximum (the hour in which the most REM sleep occurred) and the sum of REM in the light period, the passive phase (sum of duration of all REM sleep periods during 0-12 h)]. NREM sleep indexes included NREM latency [the time elapsed between light onset and the first consecutive NREM sleep episode lasting at least $3 \mathrm{~min}$, and not interrupted by more than 14 consecutive 4-s epochs, or a cumulated total of $240 \mathrm{~s}$ not scored as NREM sleep (Deboer et al., 2003; Huber et al., 1998). NREM sleep in the first and second hour (duration of NREM phase was calculated from light onset), SWS-1 and SWS-2 latencies (the time 
between light onset and the first cumulated total of a minimum 28 s of SWS-1 or SWS-2), sum of SWS-1 and SWS-2 in the light period (duration of all SWS-1 and SWS-2 sleep periods during 0-12 h)]. Quantitative analysis of NREM sleep, namely EEG power spectra of SWS-1 and SWS-2 were also performed as described above (Kantor et al., 2004).

The wake parameters around activity onset were the activity onset (defined as the hour when the duration of active wake increased by a minimum of $50 \%$ compared to the average in the passive phase) and the passive wake before activity onset (duration of passive wake during the hour preceding the activity onset). Sleep continuity was defined as the sum of the number of awakenings (either active wake or passive wake) that disconnected any sleep periods [SWS-1, SWS-2, intermediate stage of sleep (IS), or REM] during the light period, the passive phase $(0-12 \mathrm{~h})$.

\section{Statistical methods}

Statistica 7.0 software (Statsoft Inc., Tulsa, OK, USA) was used for statistical analysis. Morphological data and REM, NREM, SWS-1 and SWS-2 latencies, the sum of REM, SWS-1 and SWS-2 in the light period, passive wake before activity onset and the fragmentation of sleep were analysed using one- or two-way (treatment and time) analysis of variance (ANOVA) and Newman-Keuls test for post-hoc comparisons. REM sleep in the first hour and NREM sleep in the first and second hour were also evaluated by multivariate analysis of variance (MANOVA) for repeated measures. In the case of time of REM maximum and activity onset the Mann-Whitney $U$ test was performed. Log-transformed values were used for the statistical analysis of the EEG power spectra data.

\section{Results}

\section{5-HTT mRNA expressions in the dorsal and median raphe nuclei}

\section{Dorsal raphe nucleus}

The changes in 5-HTT mRNA expression density were quantified by film autoradiography at each time-point studied (3, 7, 21 and $180 \mathrm{~d}$ after MDMA treatment) (Figure 1a,b). Alterations in 5-HTT mRNA expression were further analysed on slides dipped into autoradiographic emulsion (Figure 2a). The levels of 5-HTT mRNA in the DRN between groups are shown in the autoradiographs in Figure 1(a). In general, significant treatment $\times$ time interaction $\left(F_{3,40}=6.369\right.$, $p=0.001$ ) was found for this parameter. A significant increase was observed $7 \mathrm{~d}$ after drug administration $(+24 \%, p<0.01)$ (Figure 1a).

To obtain more sensitive measures for the effects of MDMA, 5-HTT mRNA expression of individual cells was counted at 7 and $21 \mathrm{~d}$ after drug or saline treatment (Figure 3). We noted significantly elevated 5-HTT mRNA expression at $7 \mathrm{~d}(+53 \%, p<0.05)$ (Figures 2a, 4a, c) and significantly reduced 5-HTT mRNA expression at $21 \mathrm{~d}$ after MDMA treatment $(-22 \%, p<0.05)$ (Figures 2a, 4e, g)

MDMA did not affect the levels of 5-HTT mRNA in the DRN compared to the control group at 3 and $180 \mathrm{~d}$ after drug exposure (Figure 1a, b).

\section{Median raphe nucleus}

In the MRN, 5-HTT mRNA density was quantified by film autoradiography at each survival time (3, 7, 21 and $180 \mathrm{~d}$ after MDMA treatment) (Figure 1a, c), and the changes in 5-HTT mRNA expression were further compared by analysis of the signal from the slides dipped into autoradiographic emulsion, similar to the measurements on the DRN (Figure 2b). In general, significant treatment $\times$ time interaction $\left(F_{3,39}=4.790\right.$, $p=0.006)$ was found in the MRN. As shown in Figure 1(c), 5-HTT mRNA expression significantly decreased $21 \mathrm{~d}(-27 \%, p<0.05)$ after drug exposure in the MRN. To support these results by a more sensitive method, 5-HTT mRNA expression of individual cells was counted 7 and $21 \mathrm{~d}$ after MDMA administration. We found significant increase in the levels of 5-HTT mRNA at $7 \mathrm{~d}(+43 \%, p<0.05)$ (Figures $2 \mathrm{~b}, 4 \mathrm{~b}, \mathrm{~d})$ and significant decrease at $21 \mathrm{~d}$ after MDMA treatment $(-18 \%, p<0.05)$ (Figure $2 \mathrm{~b}, 4 \mathrm{f}, \mathrm{h})$. No differences between controls and treated animals were observed at 3 and $180 \mathrm{~d}$ after MDMA administration (Figure 1a, c). Qualitatively, all of these effects were similar to the changes observed in the DRN.

\section{Density of 5-HTT immunoreactive fibres in the brain}

\section{Cerebral cortex}

Treatment with MDMA significantly reduced 5-HTT fibre density at 7 and $21 \mathrm{~d}$ in the somatosensory (treatment effect: $F_{1,28}=37.791, p<0.0001$; Figure 5a-d) and somatomotor cortex (treatment effect: $F_{1,28}=$ 74.456, $p<0.0001$; Table 1). Significant treatment $\times$ time interaction was observed in the somatomotor cortex $\left(F_{2,56}=6.665, p=0.0025\right)$. The percentage changes in the somatosensory cortex and somatomotor cortex were similar: $-31 \%,-33 \%,-15 \%$, and $-36 \%,-32 \%,-14 \%$, at 7,21 and $180 \mathrm{~d}$ after treatment, respectively. The reduction in 5-HTT fibre 
(a) $3 d$ $7 \mathrm{~d}$
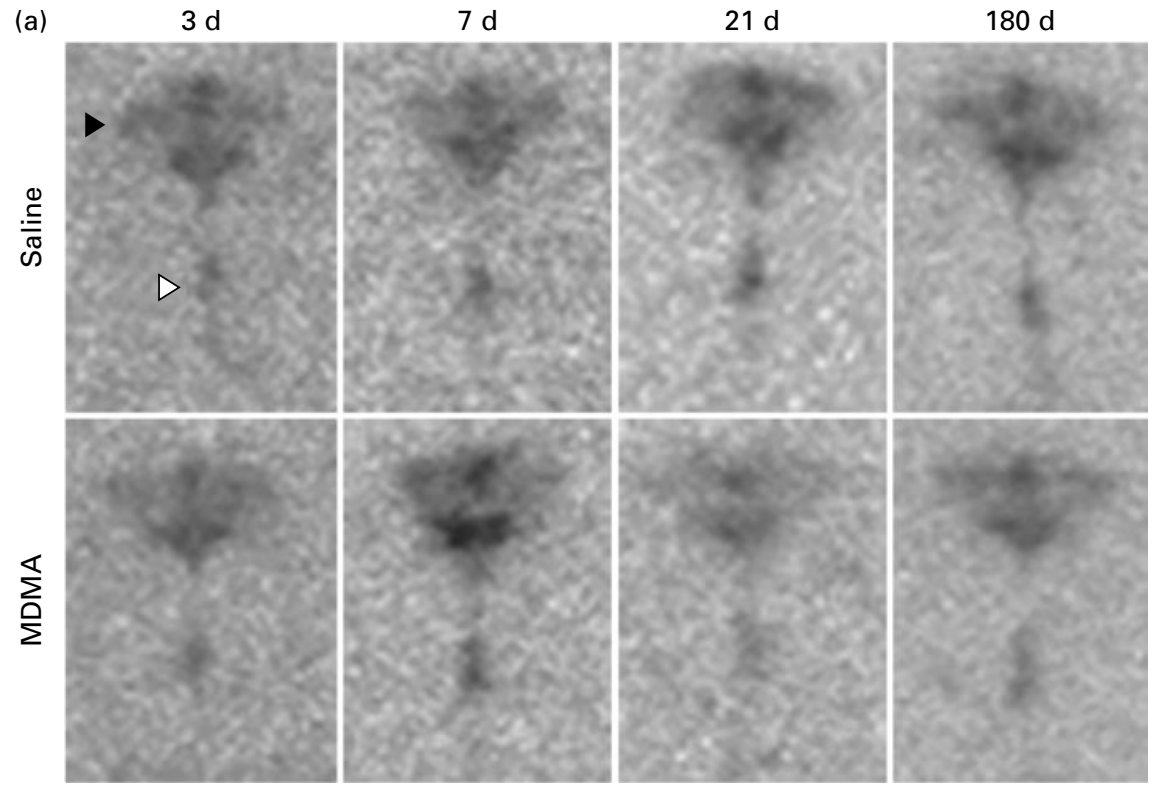

(b)
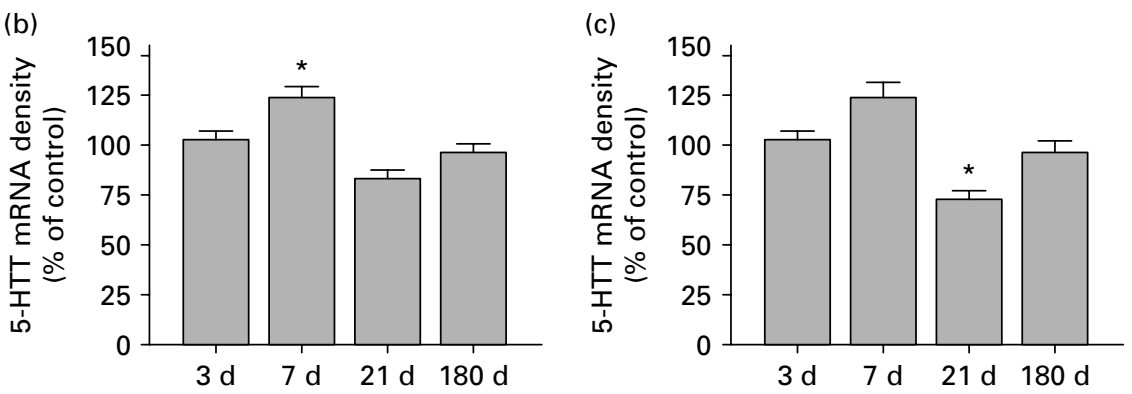

Figure 1. Expression of 5-HTT mRNA in control (saline) rats, and in rats at 3, 7, 21 and $180 \mathrm{~d}$ after treatment with a single dose of MDMA (15 mg/kg). (a) Representative autoradiographic coronal sections through the dorsal raphe nucleus (black arrowhead, $\checkmark$ ) and median raphe nucleus (white arrowhead, $\triangleright$ ) after in-situ hybridization. Effects of MDMA on 5-HTT mRNA expression density in (b) the dorsal raphe nucleus and (c) the median raphe nucleus in rats exposed to MDMA 3, 7, 21, 90 and $180 \mathrm{~d}$ earlier. 5-HTT mRNA is expressed as a relative ratio compared to controls $(\%)$. Data are mean \pm S.E.M. $(n=6) .{ }^{*}$ Significantly different compared to the saline group $(p<0.05)$.

density was not significant $180 \mathrm{~d}$ after drug exposure (Figure 5e).

\section{Hippocampus}

In the hippocampus, we found an overall decrease in the 5-HTT fibre density, which was present from day 7 up to day 180 after treatment (Table 1). We observed significant decreases in all hippocampal areas examined (CA1 treatment effect: $F_{1,28}=27.012, p<0.0001$; CA2 treatment effect: $F_{1,28}=57.202, p<0.0001$; CA3 treatment effect: $F_{1,28}=48.173, p<0.0001$ ), except for the dentate gyrus. Post-hoc tests indicated significantly reduced 5-HTT fibre density in the CA1 at all time-points examined $(-26 \%,-37 \%,-36 \%)$ (Figure $5 \mathrm{f}-\mathrm{j}), \mathrm{CA} 2(-35 \%,-41 \%,-32 \%)$ and CA3 $(-33 \%,-46 \%,-31 \%)$ at 7,21 and $180 \mathrm{~d}$ after treatment, respectively. A reduction in 5-HTT fibre density was also noted in the dentate gyrus but this change was not significant $(-24 \%,-35 \%,-19 \%$, at 7,21 and $180 \mathrm{~d}$ after treatment, respectively).

\section{Hypothalamus}

The effects of MDMA on 5-HTT fibre density were different in different hypothalamic nuclei and areas (Table 1). Reduced 5-HTT fibre density was found in the posterior hypothalamic nucleus (treatment effect: $F_{1,27}=32.256, p<0.0001$ ), SCN (treatment effect: $\left.F_{1,27}=30.423, p<0.0001\right)$ and tuberomamillary nucleus (treatment effect: $F_{1,27}=35.121, p<0.0001$ ); the lateral hypothalamic area; posteroventral preoptic areas and the paraventricular nucleus were resistant to MDMA at all time-points measured. Alterations in 5-HTT 

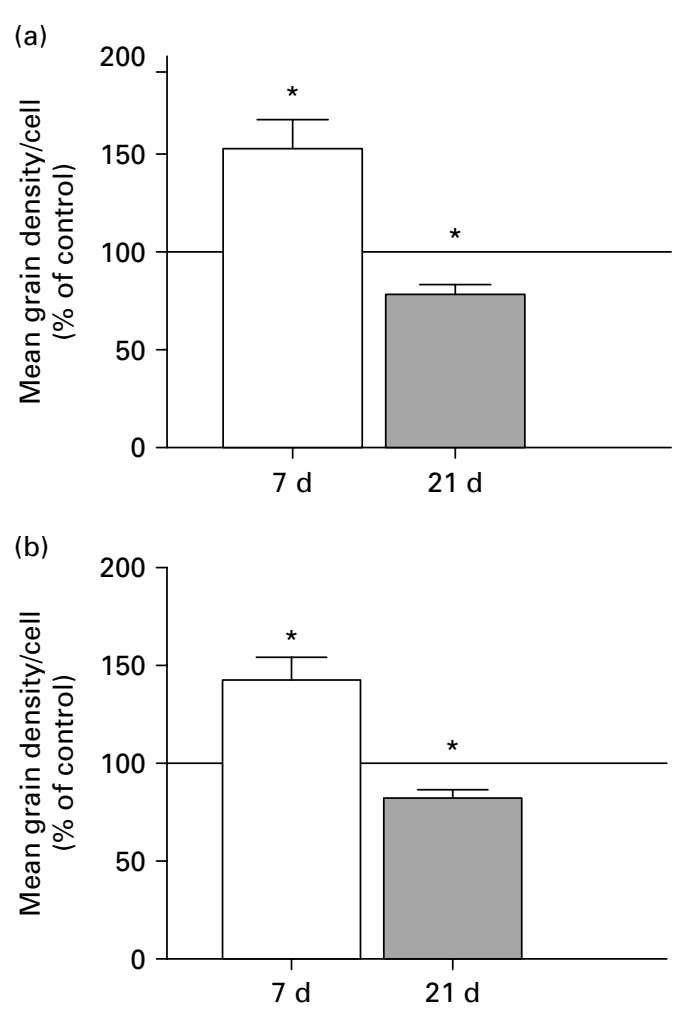

Figure 2. Quantification of 5-HTT mRNA expression by measuring grain density in individual cells of (a) the dorsal raphe nucleus and (b) the median raphe nucleus at 7 and $21 \mathrm{~d}$ after MDMA treatment. Values represent mean grain density/cell ratio relative to controls. Data are mean \pm S.E.M. $(n=6) .{ }^{*}$ Significantly different compared to the control (saline) group $(p<0.05)$.

fibre density were as follows: lateral hypothalamic area $(-12 \%,-19 \%,-8 \%)$; posterior hypothalamic nucleus $(-22 \%,-38 \%,-30 \%)$; SCN $(-30 \%,-35 \%$, $-17 \%)$; tuberomamillary nucleus $(-19 \%,-35 \%$, $-23 \%)$; posteroventral preoptic areas $(-11 \%,-17 \%$, $-2 \%)$; paraventricular nucleus $(-2 \%,-6 \%,-3 \%)$, at 7, 21 and $180 \mathrm{~d}$ after MDMA, respectively.

\section{Brainstem}

In general, changes in the brainstem were smaller, and significant alterations were observed only in two regions: the ventrolateral cell groups (treatment effect: $\left.F_{1,27}=16.452, p=0.0004\right)$ and dorsomedial cell groups (treatment effect: $F_{1,27}=15.212, p=0.0006$ ) of the periaqueductal grey matter in the midbrain, but only at $21 \mathrm{~d}$ (Table 1). The effects of MDMA on 5-HTT fibre density in the peripeduncular tegmental nucleus and the medial part of the pontine reticular formation were not significant at any time-point studied. Post-hoc comparison revealed the following changes in 5-HTT
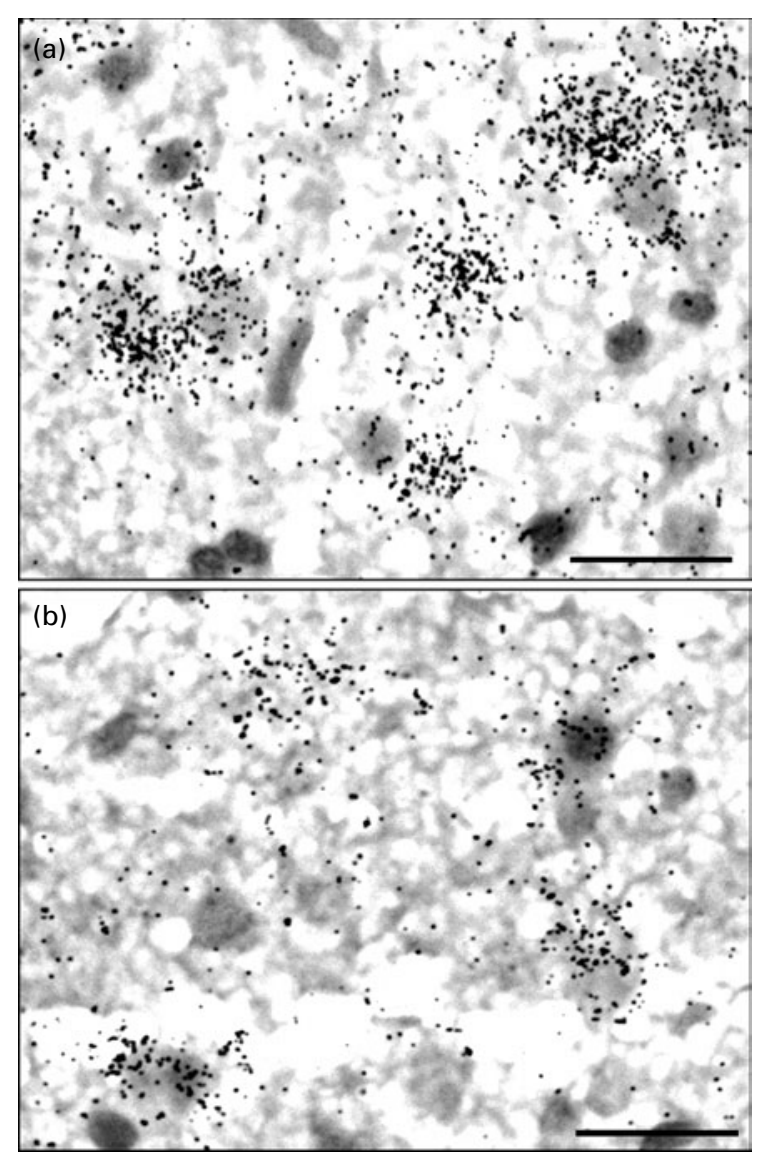

Figure 3. Bright-field image showing the cellular localization of 5-HTT mRNA in the dorsal raphe nucleus in (a) control rats, and (b) in rats $21 \mathrm{~d}$ after treatment with a single dose of MDMA. Panel (b) shows decreased grain density. Scale bars, $25 \mu \mathrm{m}$.

fibre density: periaqueductal central grey ventrolateral part $(-15 \%,-30 \%,-15 \%)$; periaqueductal central grey dorsomedial part $(-17 \%,-36 \%,-16 \%)$; peripeduncular tegmental nucleus $(-7 \%,-12 \%$, $-7 \%)$; medial pontine reticular formation $(-3 \%$, $-14 \%,-5 \%)$, at 7,21 and $180 \mathrm{~d}$ after treatment, respectively.

\section{Effects of MDMA on sleep parameters}

\section{REM sleep}

Complete $24 \mathrm{~h}$ recordings of REM sleep are shown in Figure $6(\mathrm{a}-\mathrm{c})$. In addition, four parameters, REM latency, REM in the first hour of passive phase, time of REM maximum and the sum of REM in the light period (passive phase) were measured and calculated for the characterization of onset and duration of REM sleep (Table 2). Significant decreases in REM latency were detected at 7 and $21 \mathrm{~d}$ after 

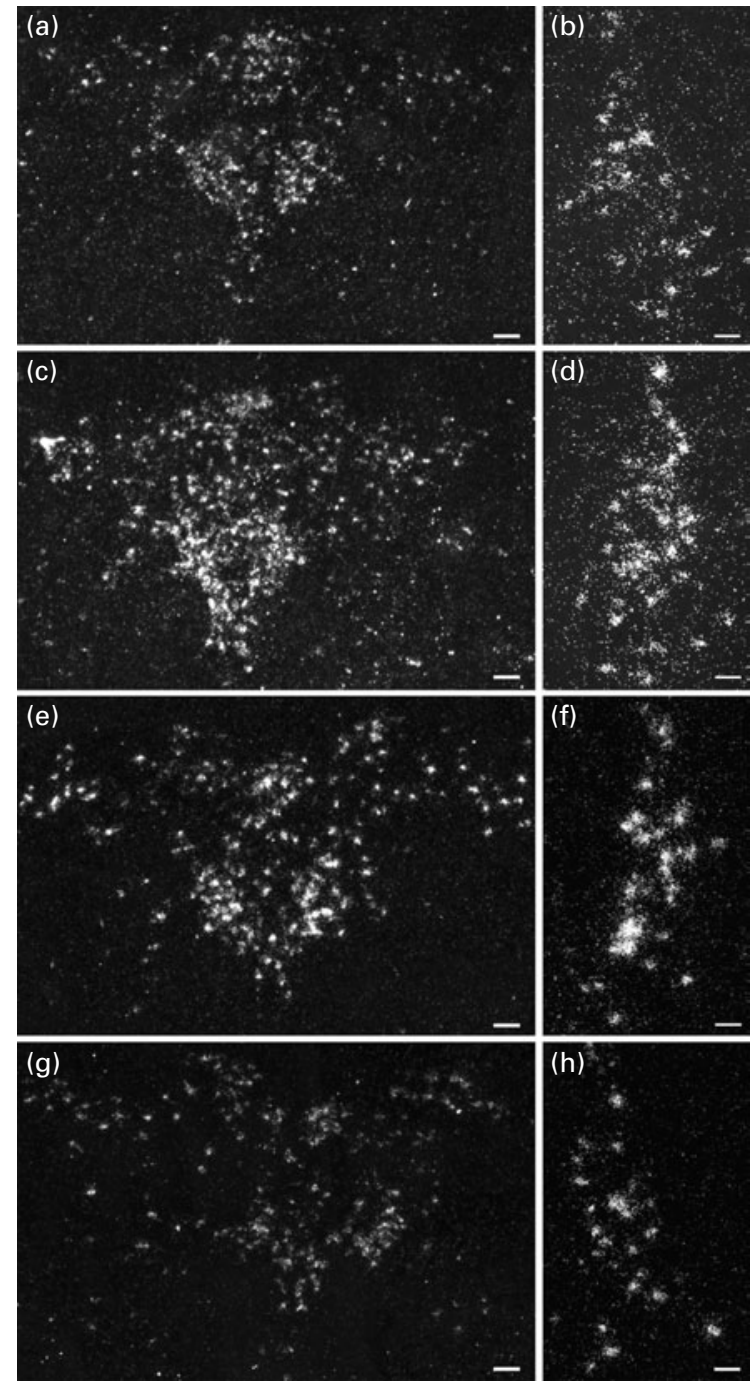

Figure 4. Dark-field images show 5-HTT mRNA expression in the dorsal raphe nucleus $(\mathrm{a}, \mathrm{c}, \mathrm{e}, \mathrm{g})$ and median raphe nucleus $(b, d, f, h)$ in control $(a, b, e, f)$ rats and in rats treated with MDMA $7 \mathrm{~d}(\mathrm{c}, \mathrm{d})$ and $21 \mathrm{~d}(\mathrm{~g}, \mathrm{~h})$ earlier. 5-HTT mRNA revealed by in-situ hybridization with a ${ }^{35}$ S-labelled ribonucleotide probe. Increased 5-HTT mRNA expression at $7 \mathrm{~d}$ following a single dose of MDMA (c, d), compared to controls $(a, b)$. A marked decrease in 5-HTT mRNA is shown in panels $(\mathrm{g})$ and $(\mathrm{h})$ at $21 \mathrm{~d}$ following a single dose of MDMA compared to controls (e, f). Scale bars: (a, c, e, g), $100 \mu \mathrm{m}$; (b, d, f, h), $50 \mu \mathrm{m}$.

MDMA administration (treatment effect: $F_{1,36}=22.880$, $p<0.0001)$. Changes in REM latency were $-55 \%$, $-53 \%$, and $-29 \%$, at 7, 21 and $180 \mathrm{~d}$ after MDMA, respectively. In parallel, increased duration of REM $(+245 \%)$ was found in the first hour of the passive phase $21 \mathrm{~d}$ after MDMA (treatment effect: $F_{1,46}=7.689$, $p=0.0079$ ). Duration of REM sleep analysed during the whole light period $(-15 \%,-34 \%,-15 \%$, at 7,21 and $180 \mathrm{~d}$ after treatment, respectively) was not significantly affected by MDMA treatment. The time of actual maximum of REM sleep was not significantly altered $(+64 \%,+30 \%,-9 \%$, at 7, 21 and $180 \mathrm{~d}$ after MDMA, respectively). At $7 \mathrm{~d}$, some MDMA-treated animals showed an extreme time-course of REM during the passive phase; REM activity showed a biphasic pattern, with the higher peak occurring very late, close to the dark phase (Figure 6a).

\section{NREM sleep}

Nine parameters (NREM latency, NREM in first and second hour, SWS-1 and SWS-2 latency, delta power SWS-1 and SWS-2 in a 2-h recording period beginning at light onset and the sum of SWS-1 and SWS-2 in the light period) were measured and calculated for the characterization of onset, duration and quality of NREM sleep (Table 2; Figure 7). Differences in NREM latency were not significant at any time-point $(-13 \%$, $-15 \%, 0 \%$, at 7,21 and $180 \mathrm{~d}$ after treatment, respectively). Neither SWS-1 (+8\%, $-51 \%, 3 \%$, at 7 , 21 and $180 \mathrm{~d}$ after treatment, respectively) nor SWS-2 latencies $(-2 \%,-6 \%, 1 \%$, at 7,21 and $180 \mathrm{~d}$ after treatment, respectively) were significantly altered by the drug. None of the parameters used for characterization of duration of NREM, NREM in the first hour $(+28 \%,+58 \%,+21 \%$, at 7,21 and $180 \mathrm{~d}$ after treatment, respectively) and second hour $(-10 \%,-4 \%$, $0 \%$, at 7, 21 and $180 \mathrm{~d}$ after treatment, respectively) were altered by MDMA at any time-point studied. Significant decreases in the sum of SWS-1 in the whole light period were found $21 \mathrm{~d}$ after MDMA treatment (treatment $\times$ time interaction: $F_{2,40}=4.847, p=0.013$; $+8 \%,-51 \%,-3 \%$, at 7,21 and $180 \mathrm{~d}$ after treatment, respectively). Delta power measured either in SWS-1 or in SWS-2 was increased by MDMA at both 7 and $21 \mathrm{~d}$ after treatment (Figure $7 \mathrm{a}, \mathrm{b}, \mathrm{d}, \mathrm{e}$ ). Changes in the lower frequencies $(1 \mathrm{~Hz}$ and $2 \mathrm{~Hz}$ ) were even more consistent. Interestingly, at day 7 , the increase in delta power was more pronounced in SWS-1; the increase shifted mainly to SWS-2 at $21 \mathrm{~d}$ (Figure $7 \mathrm{a}, \mathrm{e}$ ). In control rats, SWS-2 latency (time effect: $F_{2,42}=10.815, p=$ $0.00016)$ was increased and the sum of SWS-2 (time effect: $\left.F_{2,40}=28.235, p<0.0001\right)$ in the light period was decreased in the old animals.

\section{Wake parameters around activity onset}

Activity onset preceding the active phase was determined for each animal, in each experimental group. In general, activity was increased by $50 \%$ compared to the preceding $8-\mathrm{h}$ resting period $2-3 \mathrm{~h}$ before lights off. No significant MDMA effect was found for this 
Table 1. 5-HTT fibre density at 7, 21 and $180 \mathrm{~d}$ after MDMA $(15 \mathrm{mg} / \mathrm{kg})$ treatment in brain areas of Dark Agouti rats

\begin{tabular}{|c|c|c|c|c|c|c|}
\hline & \multicolumn{2}{|l|}{$7 \mathrm{~d}$} & \multicolumn{2}{|l|}{$21 \mathrm{~d}$} & \multicolumn{2}{|l|}{$180 \mathrm{~d}$} \\
\hline & Saline & MDMA & Saline & MDMA & Saline & MDMA \\
\hline \multicolumn{7}{|l|}{ Cerebral cortex } \\
\hline Somatosensory cortex & $6.92 \pm 0.26$ & $4.76 \pm 0.35^{*}$ & $6.02 \pm 0.33$ & $4.05 \pm 0.18^{*}$ & $6.31 \pm 0.27$ & $5.36 \pm 0.40$ \\
\hline Somatomotor cortex & $7.17 \pm 0.38$ & $4.61 \pm 0.16^{*}$ & $6.27 \pm 0.31$ & $4.29 \pm 0.28^{*}$ & $6.28 \pm 0.18$ & $5.41 \pm 0.32$ \\
\hline \multicolumn{7}{|l|}{ Hippocampus } \\
\hline CA1 & $6.33 \pm 0.47$ & $4.67 \pm 0.19^{*}$ & $4.91 \pm 0.52$ & $3.09 \pm 0.23^{*}$ & $4.48 \pm 0.55$ & $2.87 \pm 0.28^{*}$ \\
\hline CA2 & $7.08 \pm 0.16$ & $4.64 \pm 0.36^{*}$ & $5.79 \pm 0.20$ & $3.43 \pm 0.27^{*}$ & $5.37 \pm 0.67$ & $3.65 \pm 0.28^{*}$ \\
\hline CA3 & $6.07 \pm 0.25$ & $4.09 \pm 0.25^{*}$ & $6.09 \pm 0.28$ & $3.30 \pm 0.60^{*}$ & $4.79 \pm 0.43$ & $3.31 \pm 0.33^{*}$ \\
\hline Dentate gyrus & $2.78 \pm 0.18$ & $2.10 \pm 0.20$ & $2.81 \pm 0.20$ & $1.81 \pm 0.11$ & $2.80 \pm 0.36$ & $2.28 \pm 0.24$ \\
\hline \multicolumn{7}{|l|}{ Hypothalamus } \\
\hline Posteroventral preoptic areas & $5.88 \pm 0.49$ & $5.23 \pm 0.48$ & $5.52 \pm 0.44$ & $4.57 \pm 0.19$ & $4.91 \pm 0.58$ & $4.80 \pm 0.25$ \\
\hline Lateral hypothalamic area & $6.38 \pm 0.48$ & $5.60 \pm 0.43$ & $4.96 \pm 0.18$ & $4.03 \pm 0.36$ & $5.47 \pm 0.29$ & $5.04 \pm 0.32$ \\
\hline Posterior hypothalamic nucleus & $6.71 \pm 0.30$ & $5.24 \pm 0.31^{*}$ & $6.25 \pm 0.51$ & $3.89 \pm 0.40^{*}$ & $4.52 \pm 0.39$ & $3.18 \pm 0.30^{*}$ \\
\hline Paraventricular nucleus & $5.43 \pm 0.27$ & $5.29 \pm 0.46$ & $6.08 \pm 0.38$ & $5.72 \pm 0.52$ & $5.84 \pm 0.29$ & $5.68 \pm 0.27$ \\
\hline Suprachiasmatic nucleus & $6.78 \pm 0.33$ & $4.76 \pm 0.34^{*}$ & $5.53 \pm 0.46$ & $3.60 \pm 0.19^{*}$ & $4.84 \pm 0.43$ & $4.01 \pm 0.28$ \\
\hline Tuberomamillary nucleus & $5.90 \pm 0.19$ & $4.78 \pm 0.31^{*}$ & $5.95 \pm 0.36$ & $3.86 \pm 0.33^{*}$ & $5.21 \pm 0.37$ & $4.02 \pm 0.22^{*}$ \\
\hline \multicolumn{7}{|l|}{ Brainstem } \\
\hline Peripeduncular tegmental nucleus & $4.70 \pm 0.12$ & $4.38 \pm 0.28$ & $4.12 \pm 0.25$ & $3.63 \pm 0.33$ & $3.93 \pm 0.17$ & $3.65 \pm 0.46$ \\
\hline Medial pontine reticular formation & $4.23 \pm 0.32$ & $4.09 \pm 0.35$ & $2.93 \pm 0.29$ & $2.52 \pm 0.32$ & $3.22 \pm 0.30$ & $3.07 \pm 0.38$ \\
\hline \multicolumn{7}{|l|}{ Periaqueductal central grey } \\
\hline Ventrolateral part & $10.34 \pm 0.29$ & $8.82 \pm 0.39$ & $8.28 \pm 0.43$ & $5.83 \pm 0.42^{*}$ & $6.66 \pm 0.54$ & $5.64 \pm 0.71$ \\
\hline Dorsomedial part & $9.53 \pm 0.71$ & $7.92 \pm 0.58$ & $8.74 \pm 0.60$ & $5.61 \pm 0.33^{*}$ & $7.73 \pm 0.70$ & $6.47 \pm 0.77$ \\
\hline
\end{tabular}

Data are presented as mean \pm S.E.M. of $5-6$ animals per group.

* Significantly different compared to the relevant control (saline) group $(p<0.05)$.

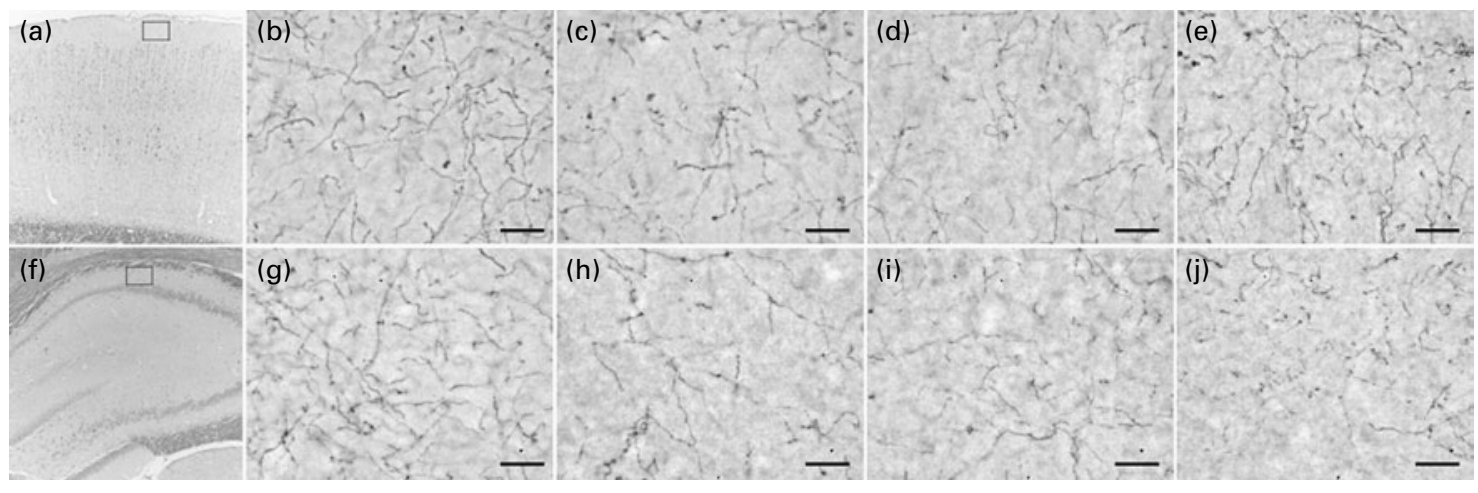

Figure 5. 5-HTT immunoreactive axons in the somatosensory cortex and in the hippocampal CA1 region. Representative photomicrographs illustrating the areas where the densitometry was applied [open rectangles in panels (a) and (f)], and 5-HTT fibre density in control $(b, g)$ and MDMA-treated rats at $7 \mathrm{~d}(\mathrm{c}, \mathrm{h}), 21 \mathrm{~d}(\mathrm{~d}, \mathrm{i})$ and $180 \mathrm{~d}(\mathrm{e}, \mathrm{j})$ after treatment. Decreases in 5-HTT fibre density can be observed in panels (c, d, h, i). Scale bars, $20 \mu \mathrm{m}$.

parameter $(+17 \%, 0 \%, 0 \%$, at 7, 21 and $180 \mathrm{~d}$ after treatment, respectively). Duration of passive wake during the hour preceding the activity alteration was also calculated. Changes in the duration of passive wake before activity onset were $+5 \%,-28 \%,-21 \%$, at 7,21 and $180 \mathrm{~d}$ after treatment, respectively. None of these parameters were significantly altered by MDMA treatment (Table 2).

\section{Sleep continuity}

The number of wake periods during the 12-h passive phase was used to characterize sleep continuity. 

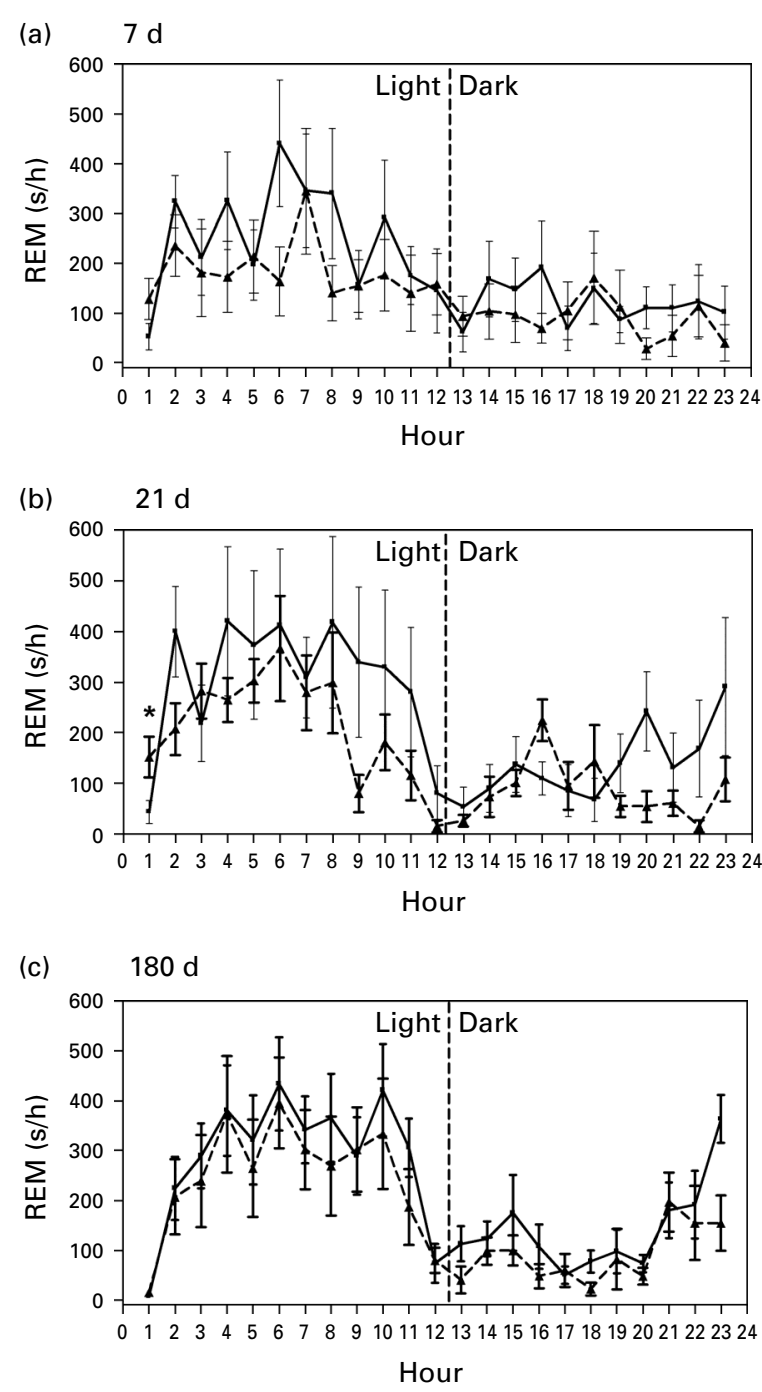

Figure 6. Twenty-four-hour recordings of rapid eye movement (REM) sleep in MDMA-treated (- - $\mathbf{\Delta - - )}$ and saline-treated (-口-) animals at $7 \mathrm{~d}(\mathrm{a}), 21 \mathrm{~d}(\mathrm{~b})$ and $180 \mathrm{~d}$ (c) after treatment. Each point represents mean values \pm S.E.M. $(n=6-8)$ of the time spent in REM sleep within each hour.

* Significantly different compared to the saline group $(p<0.05)$.

MDMA caused significant increase in this parameter but only at day $7(+83 \%,+12 \%,-32 \%$, at 7,21 and $180 \mathrm{~d}$ after treatment, respectively) (Table 2). The treatment $\times$ time interaction $\left(F_{2,41}=7.306, p=0.0019\right)$ was significant.

\section{Discussion}

Parallel measurements of 5-HTT mRNA expression in the two raphe nuclei, 5-HTT fibre density in several brain areas, and more than a dozen functional measures of sleep at three time-points within $180 \mathrm{~d}$ after MDMA administration allowed us to compare sleep disturbance with morphometric data and functions of raphe nuclei during a long period of time when the brain serotonergic system was damaged or partially recovered.

Acute and subacute effects of MDMA on sleep have been previously described by our group (Balogh et al., 2004). Here we concentrated on chronic and persistent morphological and functional effects of the drug.

In the present study, 5-HTT mRNA expression was measured in the two largest groups of ascending projecting serotonergic neurons, the DRN and the MRN. A transient increase followed by a transient decrease and a complete recovery were found during the $180-\mathrm{d}$ period in both raphe nuclei studied. The effects of MDMA on 5-HTT mRNA expression in DRN and MRN did not differ in time or extent. The up-regulation of 5-HTT mRNA expressions $7 \mathrm{~d}$ after MDMA treatment in both raphe nuclei may be explained by a compensatory phenomenon following decreased axonal transport or a possible distal downregulation of the expression of 5-HTT (Kovacs et al., 2007).

In addition, 5-HTT fibre density was also measured in a number of brain regions. Decreases were detected in several brain areas, from the brainstem up to the cerebral cortex at 7 and $21 \mathrm{~d}$. Evidence for partial recovery was found in most affected brain regions, except for the hippocampus, by $180 \mathrm{~d}$.

It is well established for several species (Hornung et al., 1990; Kosofsky and Molliver, 1987; Mulligan and Tork, 1988) that the cerebral cortex contains at least two major types of 5-HT fibres. It was suggested that the fine fibres are derived from the DRN, while thicker fibres are derived from the MRN (Kosofsky and Molliver, 1987; Mulligan and Tork, 1988). It has been reported previously that the fine serotonergic fibres are selectively vulnerable to a number of amphetamine derivatives (Mamounas and Molliver, 1988; O'Hearn et al., 1988). However, later neuroanatomical and biochemical studies suggest that DRN selectivity of these amphetamines may not be exclusive (Haring et al., 1992; Hensler et al., 1994; Mamounas and Molliver, 1988; McQuade and Sharp, 1995; O'Hearn et al., 1988). Data obtained from these studies are in accordance with the observation that fine fibres arise from both raphe nuclei (Morin and Meyer-Bernstein, 1999). Our immunohistochemical data support the conclusion that axons of MRN origin are also affected by MDMA. The origin of serotonergic projections to the SCN is almost exclusively the MRN (Glass et al., 2003; Meyer-Bernstein et al., 1999), and 
Table 2. Sleep parameters at 7, 21 and $180 \mathrm{~d}$ after MDMA $(15 \mathrm{mg} / \mathrm{kg})$ treatment

\begin{tabular}{|c|c|c|c|c|c|c|}
\hline \multirow[b]{2}{*}{ Sleep parameter } & \multicolumn{2}{|l|}{$7 \mathrm{~d}$} & \multicolumn{2}{|l|}{$21 \mathrm{~d}$} & \multicolumn{2}{|l|}{$180 \mathrm{~d}$} \\
\hline & Saline & MDMA & Saline & MDMA & Saline & MDMA \\
\hline \multicolumn{7}{|l|}{ REM sleep } \\
\hline REM latency (s) & $3745 \pm 446$ & $1676 \pm 249^{*}$ & $2937 \pm 364$ & $1383 \pm 160^{*}$ & $3511 \pm 647$ & $2485 \pm 451$ \\
\hline REM in 1st hour (s) & $53.0 \pm 26.9$ & $128.4 \pm 41.1$ & $44.0 \pm 22.6$ & $152.0 \pm 40.3^{*}$ & $8.0 \pm 5.3$ & $15.6 \pm 7.8$ \\
\hline Time of REM max (h) & $4.88 \pm 0.97$ & $8.00 \pm 1.11$ & $4.71 \pm 0.97$ & $6.13 \pm 0.58$ & $6.88 \pm 0.79$ & $6.25 \pm 0.90$ \\
\hline Sum of REM in the light period (s) & $2485 \pm 684$ & $2107 \pm 429$ & $3742 \pm 1277$ & $2453 \pm 458$ & $3465 \pm 660$ & $2959 \pm 766$ \\
\hline \multicolumn{7}{|l|}{ NREM sleep } \\
\hline NREM latency (s) & $1798 \pm 367$ & $1558 \pm 269$ & $1986 \pm 412$ & $1687 \pm 515$ & $2201 \pm 394$ & $2195 \pm 429$ \\
\hline NREM in first hour (s) & $1107 \pm 217$ & $1414 \pm 167$ & $891 \pm 127$ & $1410 \pm 248$ & $663 \pm 144$ & $801 \pm 179$ \\
\hline NREM in second hour (s) & $2230 \pm 196$ & $1998 \pm 113$ & $2280 \pm 188$ & $2188 \pm 157$ & $2136 \pm 95$ & $2133 \pm 122$ \\
\hline SWS-1 latency (s) & $1585 \pm 395$ & $1717 \pm 250$ & $1528 \pm 458$ & $746 \pm 225$ & $2008 \pm 254$ & $2064 \pm 315$ \\
\hline SWS-1 delta power $\left(\mu \mathrm{V}^{2} / \mathrm{Hz}\right)$ & $3218 \pm 254$ & $4874 \pm 588^{*}$ & $3066 \pm 139$ & $3461 \pm 87$ & $2602 \pm 205$ & $2527 \pm 456$ \\
\hline Sum of SWS-1 in the light period (s) & $7259 \pm 751$ & $6910 \pm 1139$ & $8222 \pm 770$ & $4444 \pm 287^{*}$ & $10751 \pm 1076$ & $12473 \pm 1071$ \\
\hline SWS-2 latency (s) & $1993 \pm 465$ & $1962 \pm 228$ & $2208 \pm 425$ & $2069 \pm 461$ & $3578 \pm 358$ & $3610 \pm 302$ \\
\hline SWS-2 delta power $\left(\mu \mathrm{V}^{2} / \mathrm{Hz}\right)$ & $8813 \pm 1230$ & $12005 \pm 1394$ & $7255 \pm 632$ & $11478 \pm 1108^{*}$ & $4727 \pm 321$ & $5313 \pm 723$ \\
\hline Sum of SWS-2 in the light period (s) & $16779 \pm 1400$ & $18502 \pm 1523$ & $16336 \pm 996$ & $20180 \pm 591$ & $10776 \pm 872$ & $9738 \pm 1510$ \\
\hline \multicolumn{7}{|l|}{ Wake parameters around activity onset } \\
\hline Activity onset (h) & $9.38 \pm 0.19$ & $11.00 \pm 0.72$ & $9.67 \pm 0.21$ & $9.63 \pm 0.42$ & $10.38 \pm 0.60$ & $10.38 \pm 0.53$ \\
\hline Passive wake before activity onset (s) & $501.5 \pm 87.5$ & $528.6 \pm 128.2$ & $604.0 \pm 82.8$ & $435.5 \pm 77.5$ & $611.5 \pm 141.1$ & $483.5 \pm 111.1$ \\
\hline \multicolumn{7}{|l|}{ Sleep continuity } \\
\hline Number of wakes in the light period & $209.6 \pm 20.1$ & $384.1 \pm 42.1^{*}$ & $228.6 \pm 35.0$ & $255.8 \pm 35.8$ & $176.4 \pm 28.9$ & $119.8 \pm 13.9$ \\
\hline
\end{tabular}

REM, Rapid eye movement; NREM, non-rapid eye movement; SWS-1, light slow-wave sleep; SWS-2, deep slow-wave sleep. Data are presented mean \pm S.E.M. of 7-9 animals per group.

* Significantly different compared to the saline group $(p<0.05)$.

MRN median raphe fibres project heavily throughout the entire hippocampus (Azmitia and Segal, 1978; Conrad et al., 1974; Imai et al., 1986; Vertes and Martin, 1988). The SCN and the three CA areas of the hippocampus were strongly affected by MDMA in our experiment. Furthermore, changes in 5-HTT mRNA expression in the DRN and MRN were similar in the present study. These data support the view that axons of both DRN and MRN origin are temporarily damaged by the drug.

Recovery of serotonergic neurons was observed in animals treated with a single dose of MDMA $180 \mathrm{~d}$ previously in most areas examined except for the hippocampus. This observation supports previous results that the rate and degree of recovery is region dependent (Sabol et al., 1996). Scanzello et al. (1993) found that the hippocampus is the only brain region where none of the presynaptic 5-HT neuronal markers recovered 1 yr after MDMA administration.

Our results support previous data showing that the hippocampus is more resistant to recovery compared to other brain regions. The explanation for this might be the specific hierarchy of hippocampal neurons and/or alteration of synthesis or metabolism of neurotrophic factors (Martinez-Turrillas et al., 2006). Among the consequences of these findings might be long-term changes in memory functions and/or anxiety. Indeed, human studies most consistently point to cognitive and memory disturbances in current and previous ecstasy users (Morgan, 2000; Parrott, 2001).

A selective decrease in REM latency was found at 7 and $21 \mathrm{~d}$ after MDMA administration. Similarly, an increase in the amount of REM was found in the first hour. None of the other parameters characterizing REM sleep were altered. Our data support the view that initiation of REM sleep is modulated by the serotonergic system (Adrien, 2002; Bhatti et al., 1998; Portas et al., 1996). In contrast, none of the other REM sleep parameters nor most of the NREM sleep parameters were affected by the temporary lesion of the serotonergic system in our study. It has been suggested that higher amounts of REM sleep, described in 5-HTT knockout mice (Alexandre et al., 2006; Wisor et al., 2003) result from excessive serotonergic tone during early life (Alexandre et al., 2006). Our data support this notion, because a transient decrease of 

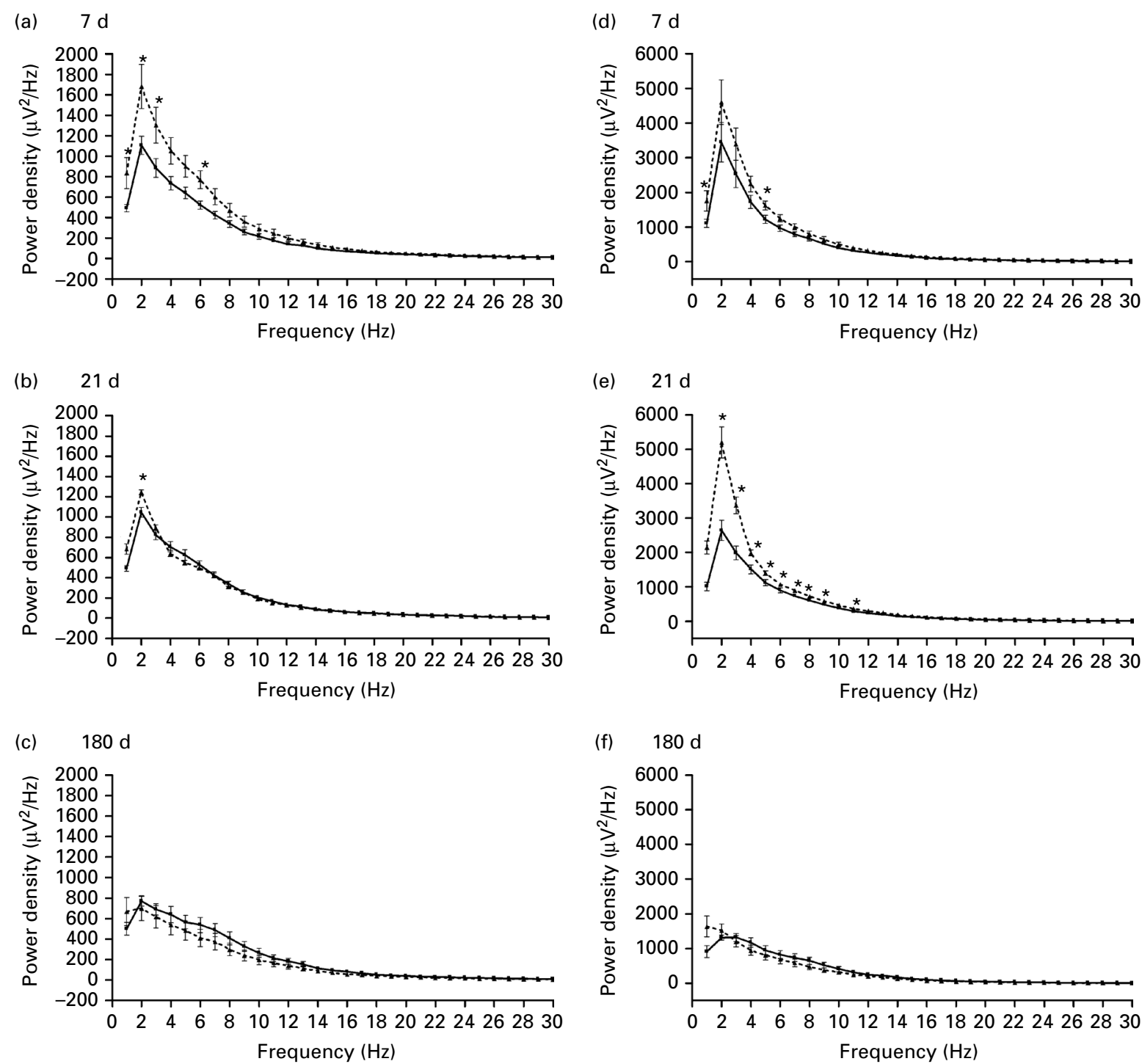

Figure 7. EEG power spectra (absolute power density) in slow-wave sleep (SWS)-1 (a-c) and SWS-2 phase (d-f) at $7 \mathrm{~d}(\mathrm{a}, \mathrm{d}), 21 \mathrm{~d}$ $(\mathrm{b}, \mathrm{e})$, and $180 \mathrm{~d}(\mathrm{c}, \mathrm{f})$ after MDMA treatment. Each point represents mean values \pm S.E.M. $(n=8)$ of $1 \mathrm{~Hz}$ bins in a 2 -h recording

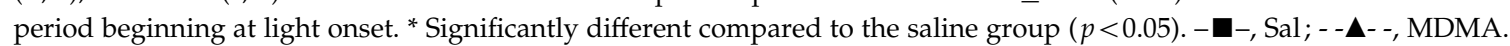

5-HTT expression together with decreased 5-HT availability observed $21 \mathrm{~d}$ after MDMA treatment failed to cause a general enhancement in the amount of REM sleep. Increase in REM sleep was restricted to the first hour of passive phase suggesting that it was caused solely by a decrease in REM latency.

MDMA administration is followed by depletions in 5-HTT fibre density in some, but not all, brain areas involved in the regulation of REM sleep examined in this study. Significant damage was found in the SCN and tuberomamillary nucleus, parallel with reduced REM latency at 7 and $21 \mathrm{~d}$ after MDMA treatment. In contrast, we could not find significant changes in
5-HTT density around the 'effector' neurons located in the medial pontine reticular formation (Sinton and McCarley, 2004) and the peripeduncular tegmental nucleus (Adrien, 2002) in the brainstem, thus, it is unlikely, that the observed decrease in REM latency could be a consequence of changes in the serotonergic system of these areas.

The decrease in REM latency induced by MDMA may be explained by a decreased inhibition of SCN by $5-\mathrm{HT}$, and consequently an earlier activation of SCN. 5-HT inhibits the spontaneous discharge of SCN neurons in vivo and in hypothalamic slices in vitro ( $\mathrm{Yu}$ et al., 2001). This effect may be mediated via $5-\mathrm{HT}_{7}$ and 
5- $\mathrm{HT}_{1 \mathrm{~B}}$ receptors (Yannielli and Harrington, 2004; Yu et al., 2001). The SCN strongly promotes REM sleep tendency during the rest phase, and the SCN neurons show increased activity during REM sleep compared to NREM sleep, the peak of the firing rate of SCN is in the middle of the passive phase when the amount of REM sleep is the highest during the day (Deboer et al., 2003; Wurts and Edgar, 2000). In conclusion, the decrease in 5-HTT fibre density in the SCN could be one possible explanation for decreased REM latency.

The importance of our findings is further supported by the fact that disturbances of sleep are typical for most depressed patients and belong to the core symptoms of depression according to DSM-IV criteria (Riemann et al., 2001). More than $90 \%$ of depressed patients complain about disturbances in sleep quality (Mendelson et al., 1977; Riemann et al., 2001). Difficulties in falling asleep, frequent nocturnal awakenings, and early morning awakening are the most frequent complaints, and reduced REM latency and increased sleep fragmentation are the most characteristic alterations described in depression using EEG sleep polygraphy (Riemann et al., 2001). MDMA has been shown to disrupt the circadian cycle in vivo and firing patterns of SCN in hypothalamic slices (Balogh et al., 2004; Colbron et al., 2002; Dafters and Biello, 2003). Furthermore, disruption of the regular cycle has been connected to serotonergic mechanisms (Biello and Dafters, 2001; Colbron et al., 2002). Our finding of altered 5-HTT densities in the SCN after MDMA treatment further supports the role of SCN in sleep disturbances caused by MDMA.

Despite the reduced REM latency, we could not find significant changes in the amount of REM sleep after REM onset. The firing rate of DRN neurons is almost absent and is also decreased in the MRN during REM sleep (McGinty and Harper, 1976; Portas et al., 1996; Urbain et al., 2006). It is more likely that during REM latency, before the onset of REM sleep, the MDMA-induced damage elicits a faster reduction of the 5-HT input, thus, the threshold will be reached earlier. The amount of REM sleep does not change after that since the 5-HT input is absent. Furthermore, the amount of REM sleep, once initiated, is determined primarily by homeostatic mechanisms (Wurts and Edgar, 2000).

Among the nine parameters of NREM sleep, only three were altered by MDMA treatment and even these alterations failed to follow the time-course of serotonergic damage. The most consistent effect was an increase in delta power during the first hours of the passive phase in NREM sleep. In addition, SWS-1 in the passive phase was decreased at $21 \mathrm{~d}$. This finding is consistent with the increase in delta power caused by $5-\mathrm{HT}_{2 \mathrm{~A}}$ receptor antagonists (Dugovic et al., 1989; Monti and Monti, 1999; Sebban et al., 2002; Ursin, 2002). Interestingly, $5-\mathrm{HT}_{2 \mathrm{~B}}$ and $5-\mathrm{HT}_{2 \mathrm{C}}$ receptor antagonists fail to cause a similar effect (Kantor et al., 2002; Popa et al., 2005). The present experiments provide evidence that a partial lesion of the serotonergic system depletes the endogenous 5-HT tone that physiologically inhibits delta activity during NREM sleep. The role of tonic inhibition of delta power by $5-\mathrm{HT}$ through $5-\mathrm{HT}_{2 \mathrm{~A}}$ receptors has been suggested on the basis of pharmacological studies (Monti and Monti, 1999; Sebban et al., 2002; Ursin, 2002)

Sleep fragmentation, an inverse measure of sleep continuity, was increased at $7 \mathrm{~d}$ after MDMA administration. Interestingly, this disturbance was normalized by day 21 , despite the continuous presence of serotonergic lesions in all brain areas.

In one study, sleep alterations were compared in MDMA users and control subjects. Significant differences were found only in NREM sleep parameters. REM latency was lower by $20 \%$ in MDMA users, but the difference was not significant. The lack of significantly decreased REM latency in MDMA users may be explained by the fact that the time elapsed from the last ecstasy use was very heterogeneous in the sample (Allen et al., 1993).

In conclusion, transient changes in the terminal and cellular regions of the ascending serotonergic system, and in parallel some altered sleep functions, were found after a single dose of MDMA. These data provide further evidence for the connection between altered serotonergic functions and sleep disturbance. Despite prolonged serotonergic damage in the hippocampus, all functional changes in sleep were normalized together with recovery of fibre density in most brain areas $180 \mathrm{~d}$ after MDMA treatment.

\section{Acknowledgements}

This study was supported by the Sixth Framework Programme of the EC, LSHM-CT-2004-503474, the Hungarian Research Fund Grant T020500, the Ministry of Welfare Research Grant 460/2006, and the Ph.D. Fellowship Programme of Semmelweis University, Ministry of Education, Hungary. The authors thank Professor I. Hermecz for providing the MDMA.

\section{Statement of Interest}

None. 


\section{References}

Adrien J (2002). Neurobiological bases for the relation between sleep and depression. Sleep Medicine Reviews 6, 341-351.

Alexandre C, Popa D, Fabre V, Bouali S, Venault P, Lesch KP, Hamon M, Adrien J (2006). Early life blockade of 5-hydroxytryptamine 1A receptors normalizes sleep and depression-like behavior in adult knock-out mice lacking the serotonin transporter. Journal of Neuroscience 26, 5554-5564.

Allen RP, McCann UD, Ricaurte GA (1993). Persistent effects of (+/-)3,4-methylenedioxymethamphetamine (MDMA, 'ecstasy') on human sleep. Sleep 16, 560-564.

Azmitia EC, Segal M (1978). An autoradiographic analysis of the differential ascending projections of the dorsal and median raphe nuclei in the rat. Journal of Comparative Neurology 179, 641-667.

Balogh B, Molnar E, Jakus R, Quate L, Olverman HJ, Kelly PA, Kantor S, Bagdy G (2004). Effects of a single dose of 3,4-methylenedioxymethamphetamine on circadian patterns, motor activity and sleep in drug-naive rats and rats previously exposed to MDMA.

Psychopharmacology (Berlin) 173, 296-309.

Battaglia G, Yeh SY, O'Hearn E, Molliver ME, Kuhar MJ, De Souza EB (1987). 3,4-Methylenedioxymethamphetamine and 3,4-methylenedioxyamphetamine destroy serotonin terminals in rat brain: quantification of neurodegeneration by measurement of $\left[{ }^{3} \mathrm{H}\right]$ paroxetine-labeled serotonin uptake sites. Journal of Pharmacology and Experimental Therapeutics 242, 911-916.

Bhatti T, Gillin JC, Seifritz E, Moore P, Clark C, Golshan S, Stahl S, Rapaport M, Kelsoe J (1998). Effects of a tryptophan-free amino acid drink challenge on normal human sleep electroencephalogram and mood. Biological Psychiatry 43, 52-59.

Biello SM, Dafters RI (2001). MDMA and fenfluramine alter the response of the circadian clock to a serotonin agonist in vitro. Brain Research 920, 202-209.

Colado MI, Granados R, O'Shea E, Esteban B,

Green AR (1999). The acute effect in rats of

3,4-methylenedioxyethamphetamine (MDEA, 'eve') on body temperature and long term degeneration of 5-HT neurones in brain: a comparison with MDMA ('ecstasy'). Pharmacology and Toxicology 84, 261-266.

Colado MI, Murray TK, Green AR (1993). 5-HT loss in rat brain following 3,4-methylenedioxymethamphetamine (MDMA), p-chloroamphetamine and fenfluramine administration and effects of chlormethiazole and dizocilpine. British Journal of Pharmacology 108, 583-589.

Colbron S, Jones M, Biello SM (2002). MDMA alters the response of the circadian clock to a photic and non-photic stimulus. Brain Research 956, 45-52.

Conrad LC, Leonard CM, Pfaff DW (1974). Connections of the median and dorsal raphe nuclei in the rat: an autoradiographic and degeneration study. Journal of Comparative Neurology 156, 179-205.
Dafters RI, Biello SM (2003). The effect of

3,4-methylenedioxymethamphetamine ('Ecstasy') on serotonergic regulation of the mammalian circadian clock mechanism in rats: the role of dopamine and hyperthermia. Neuroscience Letters 350, 117-121.

Deboer T, Vansteensel MJ, Detari L, Meijer JH (2003). Sleep states alter activity of suprachiasmatic nucleus neurons. Nature Neuroscience 6, 1086-1090.

Dugovic C, Wauquier A, Leysen JE, Marrannes R, Janssen PA (1989). Functional role of 5-HT2 receptors in the regulation of sleep and wakefulness in the rat. Psychopharmacology (Berlin) 97, 436-442.

Filakovszky J, Kantor S, Halasz P, Bagdy G (2001). 8-OH-DPAT and MK-801 affect epileptic activity independently of vigilance. Neurochemistry International 38, 551-556.

Glass JD, Grossman GH, Farnbauch L, DiNardo L (2003). Midbrain raphe modulation of nonphotic circadian clock resetting and 5-HT release in the mammalian suprachiasmatic nucleus. Journal of Neuroscience 23, 7451-7460.

Gottesmann C (1992). Detection of seven sleep-waking stages in the rat. Neuroscience \& Biobehavioral Reviews 16, 31-38.

Green AR, Mechan AO, Elliott JM, O'Shea E, Colado MI (2003). The pharmacology and clinical pharmacology of 3,4-methylenedioxymethamphetamine (MDMA, 'ecstasy'). Pharmacological Reviews 55, 463-508.

Hansson SR, Mezey E, Hoffman BJ (1998). Serotonin transporter messenger RNA in the developing rat brain: early expression in serotonergic neurons and transient expression in non-serotonergic neurons. Neuroscience 83, 1185-1201.

Haring JH, Meyerson L, Hoffman TL (1992). Effects of para-chloroamphetamine upon the serotonergic innervation of the rat hippocampus. Brain Research 577, 253-260.

Hensler JG, Ferry RC, Labow DM, Kovachich GB, Frazer A (1994). Quantitative autoradiography of the serotonin transporter to assess the distribution of serotonergic projections from the dorsal raphe nucleus. Synapse 17, 1-15.

Hornung JP, Fritschy JM, Tork I (1990). Distribution of two morphologically distinct subsets of serotoninergic axons in the cerebral cortex of the marmoset. Journal of Comparative Neurology 297, 165-181.

Huber R, Deboer T, Schwierin B, Tobler I (1998). Effect of melatonin on sleep and brain temperature in the Djungarian hamster and the rat. Physiology \& Behavior 65, $77-82$.

Imai H, Steindler DA, Kitai ST (1986). The organization of divergent axonal projections from the midbrain raphe nuclei in the rat. Journal of Comparative Neurology 243, 363-380.

Kantor S, Jakus R, Balogh B, Benko A, Bagdy G (2004). Increased wakefulness, motor activity and decreased theta activity after blockade of the 5-HT2B receptor by the subtype-selective antagonist SB-215505. British Journal of Pharmacology 142, 1332-1342. 
Kantor S, Jakus R, Bodizs R, Halasz P, Bagdy G (2002). Acute and long-term effects of the 5-HT2 receptor antagonist ritanserin on EEG power spectra, motor activity, and sleep: changes at the light-dark phase shift. Brain Research 943, 105-111.

Kantor S, Jakus R, Molnar E, Gyongyosi N, Toth A, Detari L, Bagdy G (2005). Despite similar anxiolytic potential, the 5-hydroxytryptamine 2C receptor antagonist SB-242084 [6-chloro-5-methyl-1-[2-(2-methylpyrid-3-yloxy)-pyrid5-yl carbamoyl] indoline] and chlordiazepoxide produced differential effects on electroencephalogram power spectra. Journal of Pharmacology and Experimental Therapeutics 315, 921-930.

Koella WP, Feldstein A, Czicman JS (1968). The effect of para-chlorophenylalanine on the sleep of cats. Electroencephalography and Clinical Neurophysiology 25, 481-490.

Kosofsky BE, Molliver ME (1987). The serotoninergic innervation of cerebral cortex: different classes of axon terminals arise from dorsal and median raphe nuclei. Synapse 1, 153-168.

Kovacs GG, Ando RD, Adori C, Kirilly E, Benedek A, Palkovits M, Bagdy G (2007). Single dose of MDMA causes extensive decrement of serotoninergic fibre density without blockage of the fast axonal transport in Dark Agouti rat brain and spinal cord. Neuropathology and Applied Neurobiology 33, 193-203.

Mamounas LA, Molliver ME (1988). Evidence for dual serotonergic projections to neocortex: axons from the dorsal and median raphe nuclei are differentially vulnerable to the neurotoxin p-chloroamphetamine (PCA). Experimental Neurology 102, 23-36.

Martinez-Turrillas R, Moyano S, Del Rio J, Frechilla D (2006). Differential effects of 3,4-methylenedioxymethamphetamine (MDMA, 'ecstasy') on BDNF mRNA expression in rat frontal cortex and hippocampus. Neurosci Letters 402, 126-130.

McCann UD, Szabo Z, Scheffel U, Dannals RF, Ricaurte GA (1998). Positron emission tomographic evidence of toxic effect of MDMA ('Ecstasy') on brain serotonin neurons in human beings. Lancet 352, 1433-1437.

McCann UD, Szabo Z, Seckin E, Rosenblatt P, Mathews WB, Ravert HT, Dannals RF, Ricaurte GA (2005). Quantitative PET studies of the serotonin transporter in MDMA users and controls using $\left[{ }^{11} \mathrm{C}\right] \mathrm{McN} 5652$ and $\left[{ }^{[1} \mathrm{C}\right] \mathrm{DASB}$. Neuropsychopharmacology 30, 1741-1750.

McGinty DJ, Harper RM (1976). Dorsal raphe neurons: depression of firing during sleep in cats. Brain Research 101, 569-575.

McQuade R, Sharp T (1995). Release of cerebral 5-hydroxytryptamine evoked by electrical stimulation of the dorsal and median raphe nuclei: effect of a neurotoxic amphetamine. Neuroscience 68 1079-1088.

Mendelson WB (1996). Sleep induction by microinjection of pentobarbital into the medial preoptic area in rats. Life Sciences 59, 1821-1828.
Mendelson WB, Gillin JC, Wyatt RD (1977). Human Sleep and its Disorders. New York: Plenum Press.

Meyer-Bernstein EL, Jetton AE, Matsumoto SI, Markuns JF, Lehman MN, Bittman EL (1999). Effects of suprachiasmatic transplants on circadian rhythms of neuroendocrine function in golden hamsters. Endocrinology 140, 207-218.

Molliver ME, Mamounas LA, Wilson MA (1989). Effects of neurotoxic amphetamines on serotonergic neurons: immunocytochemical studies. NIDA Research Monographs 94, 270-305.

Monti JM, Monti D (1999). Functional role of serotonin 5-HT1 and 5-HT2 receptors in the regulation of REM sleep. In: Mallick BN, Inoue S (Eds.), Rapid Eye Movement Sleep (pp. 142-152). New York: Marcel Dekker.

Morgan MJ (2000). Ecstasy (MDMA), a review of its possible persistent psychological effects. Psychopharmacology (Berlin) 152, 230-248.

Morin LP, Meyer-Bernstein EL (1999). The ascending serotonergic system in the hamster: comparison with projections of the dorsal and median raphe nuclei. Neuroscience 91, 81-105.

Mulligan KA, Tork I (1988). Serotoninergic innervation of the cat cerebral cortex. Journal of Comparative Neurology 270 86-110.

O'Hearn E, Battaglia G, De Souza EB, Kuhar MJ, Molliver ME (1988). Methylenedioxyamphetamine (MDA) and methylenedioxymethamphetamine (MDMA) cause selective ablation of serotonergic axon terminals in forebrain: immunocytochemical evidence for neurotoxicity. Journal of Neuroscience 8, 2788-2803.

Parrott AC (2001). Human psychopharmacology of Ecstasy (MDMA): a review of 15 years of empirical research. Human Psychopharmacology 16, 557-577.

Paxinos G, Watson C (2005). The Rat Brain in Stereotaxic Coordinates. San Diego, CA: Academic Press Inc.

Popa D, Lena C, Fabre V, Prenat C, Gingrich J, Escourrou P, Hamon M, Adrien J (2005). Contribution of 5-HT2 receptor subtypes to sleep-wakefulness and respiratory control, and functional adaptations in knock-out mice lacking 5-HT2A receptors. Journal of Neuroscience 25, 11231-11238.

Portas CM, Thakkar M, Rainnie D, McCarley RW (1996). Microdialysis perfusion of 8-hydroxy-2-(di-npropylamino)tetralin (8-OH-DPAT) in the dorsal raphe nucleus decreases serotonin release and increases rapid eye movement sleep in the freely moving cat. Journal of Neuroscience 16, 2820-2828.

Riemann D, Berger M, Voderholzer U (2001). Sleep and depression-results from psychobiological studies: an overview. Biological Psychology 57, 67-103.

Sabol KE, Lew R, Richards JB, Vosmer GL, Seiden LS (1996). Methylenedioxymethamphetamine-induced serotonin deficits are followed by partial recovery over a 52-week period. Part I: Synaptosomal uptake and tissue concentrations. Journal of Pharmacology and Experimental Therapeutics 276, 846-854.

Scanzello CR, Hatzidimitriou G, Martello AL, Katz JL, Ricaurte GA (1993). Serotonergic recovery after 
(+/-)3,4-(methylenedioxy) methamphetamine injury: observations in rats. Journal of Pharmacology and Experimental Therapeutics 264, 1484-1491.

Sebban C, Tesolin-Decros B, Ciprian-Ollivier J, Perret L, Spedding M (2002). Effects of phencyclidine (PCP) and MK 801 on the EEGq in the prefrontal cortex of conscious rats; antagonism by clozapine, and antagonists of AMPA-, alpha(1)- and 5-HT(2A)-receptors. British Journal of Pharmacology 135, 65-78.

Semple DM, Ebmeier KP, Glabus MF, O'Carroll RE, Johnstone EC (1999). Reduced in vivo binding to the serotonin transporter in the cerebral cortex of MDMA ('ecstasy') users. British Journal of Psychiatry 175, 63-69.

Sinton CM, McCarley RW (2004). Neurophysiological mechanisms of sleep and wakefulness: a question of balance. Seminars in Neurology 24, 211-223.

Sommerfelt L, Ursin R (1991). Behavioral, sleep-waking and EEG power spectral effects following the two specific 5-HT uptake inhibitors zimeldine and alaproclate in cats. Behav Brain Res 45, 105-115.

Touret M, Sarda N, Gharib A, Geffard M, Jouvet M (1991). The role of 5-hydroxytryptophan (5-HTP) in the regulation of the sleep/wake cycle in parachlorophenylalanine ( $\mathrm{p}-\mathrm{CPA})$ pretreated rat: a multiple approach study. Experimental Brain Research 86, 117-124.
Urbain N, Creamer K, Debonnel G (2006).

Electrophysiological diversity of the dorsal raphe cells across the sleep-wake cycle of the rat. Journal of Physiology 573, 679-695.

Ursin R (2002). Serotonin and sleep. Sleep Medicine Reviews 6, 55-69.

Vertes RP, Martin GF (1988). Autoradiographic analysis of ascending projections from the pontine and mesencephalic reticular formation and the median raphe nucleus in the rat. Journal of Comparative Neurology 275, 511-541.

Wisor JP, Wurts SW, Hall FS, Lesch KP, Murphy DL, Uhl GR, Edgar DM (2003). Altered rapid eye movement sleep timing in serotonin transporter knockout mice. Neuroreport 14, 233-238.

Wurts SW, Edgar DM (2000). Circadian and homeostatic control of rapid eye movement (REM) sleep : promotion of REM tendency by the suprachiasmatic nucleus. Journal of Neuroscience 20, 4300-4310.

Yannielli P, Harrington ME (2004). Let there be 'more' light: enhancement of light actions on the circadian system through non-photic pathways. Progress in Neurobiology 74, 59-76.

Yu GD, Liu YL, Jiang XH, Guo SY, Zhang HQ, Yin QZ, Hisamitsu T (2001). The inhibitory effect of serotonin on the spontaneous discharge of suprachiasmatic neurons in hypothalamic slice is mediated by $5-\mathrm{HT}(7)$ receptor. Brain Research Bulletin 54, 395-398. 